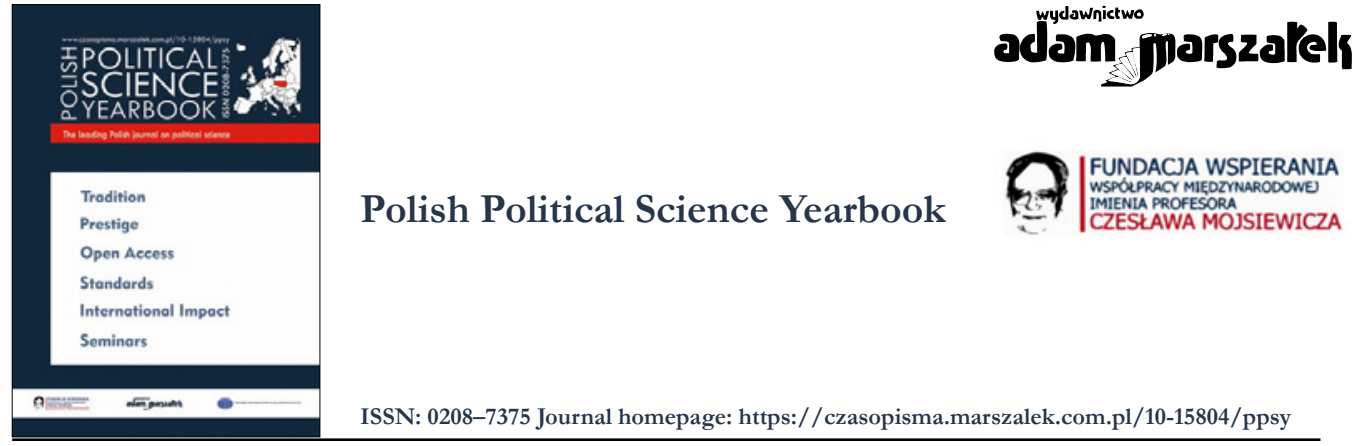

\title{
The Forecast of the Number of Soldiers in the Saudi Arabian Army in Terms of Military Security
}

\section{Bartosz Kozicki ${ }^{1}$, Szymon Mitkow ${ }^{2}$, Jarosław Zelkowski Mariusz Gontarczyk ${ }^{4}$}

ORCID: 0000-0001-6089-952X ${ }^{1}, 0000-0003-2845-2589^{2}, 0000-0002-6698-2938^{3}$, 0000-0003-1512-4092

To cite this article please include the following information:

- Journal title: Polish Political Science Yearbook

- Volume number: 50

- Year of publication: 2021

- Published ahead-of-print

Example styles:

[APA Style]: Kozicki, B., Mitkow, S., Zelkowski, J. (2021). The Forecast of the Number of Soldiers in the Saudi Arabian Army in terms of Military Security. Polish Political Science Yearbook, 50(issue number), pages. https://doi.org/10.15804/ppsy202147

[Chicago Style]: Bartosz Kozicki, Szymon Mitkow, Jarosław Zelkowski, “The Forecast of the Number of Soldiers in the Saudi Arabian Army in terms of Military Security" Polish Political Science Yearbook 50, no. [issue number] (2021).

To link to this article: https://doi.org/10.15804/ppsy202147

Published ahead-of-print

Final submission: 16 September 2021

Published online: 25 September 2021

Printed issue: 2021

Submit your article to PPSY 


\section{Bartosz Kozicki}

Military University of Technology (Poland)

ORCID: 0000-0001-6089-952X

e-mail: bartosz.kozicki@wat.edu.pl

\section{Szymon Mitkow}

Military University of Technology (Poland)

ORCID: 0000-0003-2845-2589

e-mail: szymon.mitkow@wat.edu.pl
Jarosław Zelkowski

Military University of Technology (Poland)

ORCID: 0000-0002-6698-2938

e-mail: jaroslaw.zelkowski@wat.edu.pl

Mariusz Gontarczyk

Military University of Technology (Poland)

ORCID: 0000-0003-1512-4092

e-mail: mgontarczyk@wat.edu.pl

\title{
The Forecast of the Number of Soldiers in the Saudi Arabian Army in Terms of Military Security
}

\begin{abstract}
The study concerns forecasting the number of soldiers in the Saudi Arabian army based on information obtained from the website: https://data.worldbank.org (The World Bank, 9.03.2020). The research began with a comparative analysis of the number of soldiers in the armies of Saudi Arabia and Russia. The idea for a comparative analysis of the number of armies of Saudi Arabia and the Russian Federation arises from Russian policy in the region of the Middle East countries, including the impact on world oil prices. The comparative analysis showed the similarities and differences in the dynamics of changes in the number of both armies dynamically. Subsequently, the primary time series data analysis on the number of Saudi Arabian troops was performed. The study selected methods for predicting raw data: Holt's exponential smoothing and Klein's model for the future. The next stage of the research was forecasting and the analysis and evaluation of the obtained forecasts. Klein's model was the best forecasting model. The forecast of the number of soldiers in the Saudi Arabian army for 2020 is 251454, and for 2021, it has increased to 251006. The study ends with a summary and conclusions.
\end{abstract}

Keywords: human resources policy, forecasting, the Armed Forces of Saudi Arabia, Russia's policy, military security 


\section{Introduction}

Each organization is focused on the goals it sets. They are accomplished through three essential production factors: personnel, resources, and work items. A crucial production factor is personnel as a human resource that determines the functioning and condition of the organization. Therefore, one of the main tasks of building a personnel strategy in an organization is the optimal planning of personnel resources.

The research problem of the article focuses on the answer to the question: Will the analysis and assessment of the number of Saudi Arabia soldiers in 2012-2018 allow choosing a method for forecasting them for 2019-2021? The purpose of the work was outlined for the adopted research problem.

The study aims to perform a comparative analysis of the number of soldiers of the Russian Federation and Saudi Arabia and forecast the number of Saudi Arabia soldiers for 2018-2021.

A research hypothesis has been drawn up for the research problem and the purpose of the work so adopted. The research hypothesis is: What assessment can be given to the prognosis obtained in the development?

The research period covers 1992-2021.

The research subject is the armies of Saudi Arabia and Russia, while the object is the number of soldiers in the armies of Saudi Arabia and Russia in dynamic terms.

The article reviews the literature on issues related to personnel strategy, the number of soldiers in the army of the Russian Federation, Saudi Arabia, and forecasting. A prediction method based on Holt exponential smoothing and Klein's model of the time series of retrospective data of Saudi Arabian troops was used.

\section{Analysis of the Literature on the Research Object}

The personnel policy of each organization is directly related to the determination of the size and structure of employment, and the management of human resources called personnel from the point of view of implemented or future goals. The personnel strategy of human resources management "includes decisions that are fundamental and far-reaching for employment and development policy in the enterprise, as well as those that affect the relationship between management and personnel" (Armstrong, 2007, p. 56). Employment planning is essential, as well as managing the existing human resources. Human resource management means a strategic and consistent method of managing the most important asset, i.e., people who individually and collectively contribute to achieving a company's goals and strengthen its competitive advantage (Armstrong, 2007,p. 14). To sum up, every organization must have adequate means and resources at a given time to function correctly.

One such organization is the Saudi Arabian Armed Forces. The literature analysis shows that from 1990 - the period of the first Gulf War - the number of soldiers in the Saudi Arabian 
army began to increase (The World Bank, 2020). The political and economic situation in Russia also had an impact on growth. The Saudi Arabian army is considered the best equipped in the Persian Gulf region (Urban, 2016). According to the Stockholm International Peace Research Institute (SIPRI), in 2018, Saudi Arabia was recognized as the world's largest arms importer, and its expenses amounted to USD 67.5 billion (Defence24,2019). Information on websites shows that despite Saudi Arabia having modern weapons, often better than many European countries, its actual combat capabilities are much lower than those of the less equipped armies (Kucharczyk, 2021). It is due to limitations related to the culture, training, social class of individual soldiers of the Saudi Arabian army and its number (Kucharczyk, 2021). According to M. Kucharczyk, the Arabs do not show initiative, improvisation skills, and quick decision-making (2021).

The United States has been the leading supplier of military equipment and new technologies for Saudi Arabia for many years. Saudi Arabia is afraid of the creation by Iran of a coalition against it with the participation of Iraq, Lebanon, Syria, Yemen, and Bahrain (Legucka, 2017). One of the possible threats is the foreign policy of the Russian Federation toward Syria, which is sometimes contrary to the one practiced by the United States and Saudi Arabia (Legucka, 2017; Szcześniak, 2020).

Thus, the issues related to the comparative analysis of the number of soldiers in the Armed Forces of Saudi Arabia and Russia and the forecasting of the number of soldiers in the Saudi Arabian army in dynamic terms are becoming extremely important from the point of view of the subject of the work. A critical analysis of the literature on the terms forecast and forecasting shows that the authors interpret them differently. P. Dittmann (2016) states that "a forecast is a judgment about the future of a forecast phenomenon - precise and uncertain" (p. 9). On the other hand, Z. Czerwiński (1980) believes that "a forecast is a judgment about the occurrence of a specific event at a time specified with an accuracy to the moment or period belonging to the future" (p. 19). Whereas, E. Nowak (1998) points out that the forecast is a predicted judgment on developing future phenomena and processes based on basic sciences (p. 10). What is more, a forecast is a judgment in various aspects, according to M. Cieślak (2001, pp. 18-20) and J.B. Gajda (2001, p. 135). The analysis of the forecast term shows that it is the result of the forecasting performed.

The literature analysis concludes that forecasting should be based on time data regarding future events gathered or on the analysis of the values of random variables. The selection of the prognostic method depends on the evaluation of the performed analysis of the time series components (Kozicki, 2018; Kozicki, 2020; Makridakis, Wheelwright, \& Hyndman, 1998).

There are many different classifications of forecasting methods in the literature, but one of the most commonly used is the division into quantitative and qualitative methods. In this study, Holt's exponential smoothing and Klein's model are used. Forecasting the number of Saudi Arabian soldiers is important in maintaining and ensuring the country's military security. According to W. Kitler, military security is a kind of national security, the main goal 
of which is to counteract external and internal threats that may lead to the threat of using military force to protect and defend against the threats that arise (Kitler, 2011, p. 47). One of the security threats to Saudi Arabia and the Russian Federation in 2020 has undoubtedly become the infectious disease COVID-19. The first case was reported in December 2019 in Wuhan Province, China (Zhu, Zhang, Wang et al., 2020). As a result of the rapid spread of the disease and the increasing number of human deaths worldwide, on March 11,2020, the World Health Organization announced the COVID-19 pandemic (Satomi et al., 2020). At that time, there was a general concern among people about the threat to life, and the governments of individual countries began to introduce restrictions aimed at stopping the spread of infectious diseases (Matuka, 2020).

\section{Comparative Analysis of the Size of the Armies of Saudi Arabia and Russia}

The research began with preparing a line graph of the primary data on the strength of the Saudi Arabian and Russian armies in 1992-2018 (Figure 1).

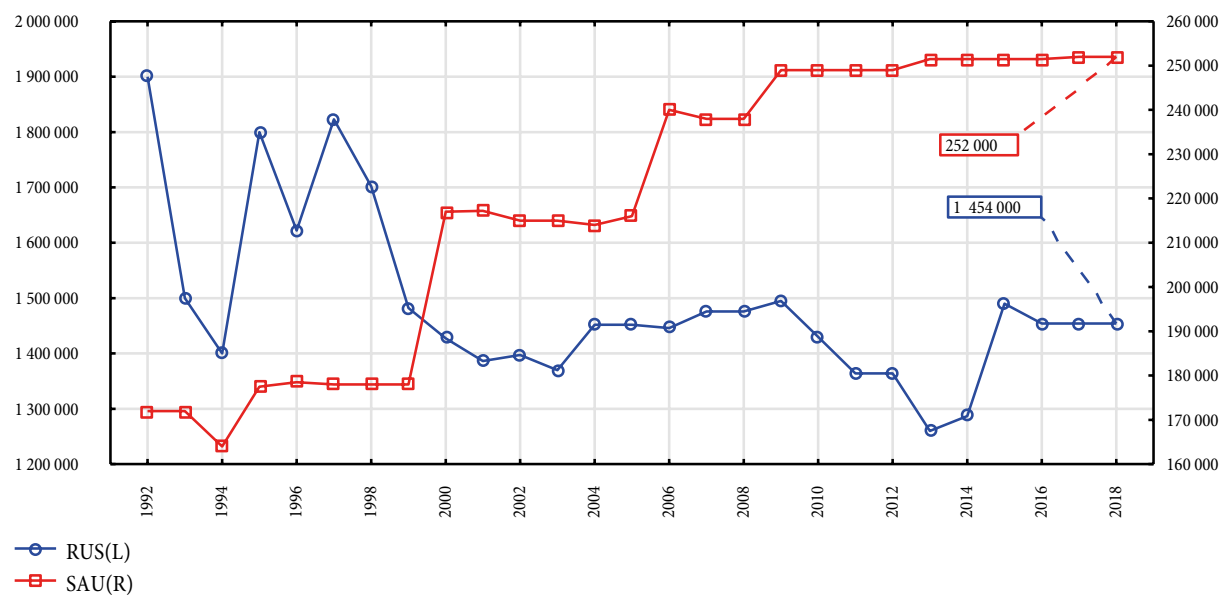

Figure 1. A line graph of primary data on the size of the armies of Saudi Arabia (right axis Y) and Russia (left axis Y) between 1992-2018

Source: own study based on: The World Bank, March 9, 2020

The primary data presented in Figure 1 shows a growing trend in the Saudi Arabian army between 1992 and 2018. On the other hand, in Russia, the number of soldiers between 1992-2018 fluctuated around the arithmetic mean of 1487530, showing a decreasing trend. It should also be added that in the Saudi Arabian army in 1992-2018, the number of soldiers fluctuated around the arithmetic mean of 219044. According to primary data, it can be clearly 
stated that the number of soldiers in the Russian army in 2018 was 5,77 times greater than in the Saudi Arabian army.

The observation of primary data and the own experience became the premises for shortening the two-time series under consideration by 1992-1999, as the data they contained were very distant and developed under entirely different political and economic conditions. Then, the shortened time series were analyzed and evaluated in the study of dependencies, using research tools such as the analysis of descriptive statistics (Table 1) and the index of dynamics on a constant basis (Figure 2).

Table 1. Analysis of descriptive statistics of primary data

\begin{tabular}{lccrrrrrrr}
\hline & N & $\begin{array}{c}\text { Arithmetic } \\
\text { mean }\end{array}$ & Med. & Sum & Min & Max & $\begin{array}{c}\text { Standard } \\
\text { deviation }\end{array}$ & $\begin{array}{c}\text { Skew- } \\
\text { ness }\end{array}$ & Kurtosis \\
\hline RUS & 19 & 1417589 & 1446000 & 26934200 & 126000 & 1495000 & 65312,23 & 1,14 & 0,80 \\
\hline SAU & 19 & 237695 & 249000 & 4516200 & 214000 & 252000 & 15984,14 & $-0,64$ & $-1,53$ \\
\hline
\end{tabular}

Source: own study based on: The World Bank, March 9, 2020

The analysis of descriptive statistics conducted in Table 1 shows that the time series of the primary data of Russia was skew to the right and slenderer than usual. In the Saudi Arabian army time series, the distribution was left skew, more flattened than average. The largest standard deviation from the mean was recorded in Russia, and it amounted to 65312,23, while in Saudi Arabia, it was 15984,14 soldiers. The low standard deviation level indicates a lower number of Saudi Arabia soldiers, as does the low level of indices in the form of the arithmetic mean (237 695 - Saudi Arabia) and median (249 000 - Saudi Arabia).

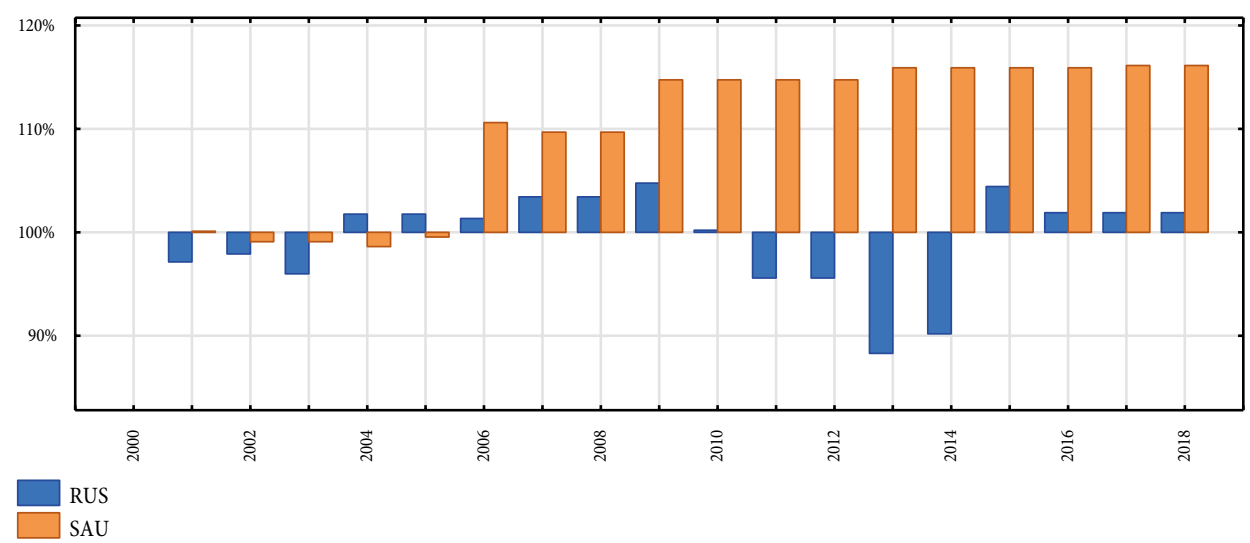

Figure 2. Bar chart of the dynamics index at a constant basis (2000) of the number of soldiers in the armies of Saudi Arabia and Russia Source: own study based on: The World Bank, March 9, 2020 
Then, analysis and evaluation of the dynamics indices of the size of Saudi Arabia and Russian armies in 2000-2018 were conducted (Figure 2).

The information presented in Figure 2 shows that the dynamics index with a constant basis for the analyzed time series of Saudi Arabia showed a strong upward trend. On the other hand, the indices of the second time series were alternately positive and negative every few elements, which indicates the absence of a trend in dynamic terms.

\section{Forecasting the Strength of the Saudi Arabian Army}

The next part of the study is a detailed analysis of the time series of the number of soldiers in the Saudi Arabian army in terms of its forecasting for 2019-2021. The first stage of the research was to search for outliers and extreme values in the considered primary time series. For this purpose, a research tool in the form of a box plot graph was used.

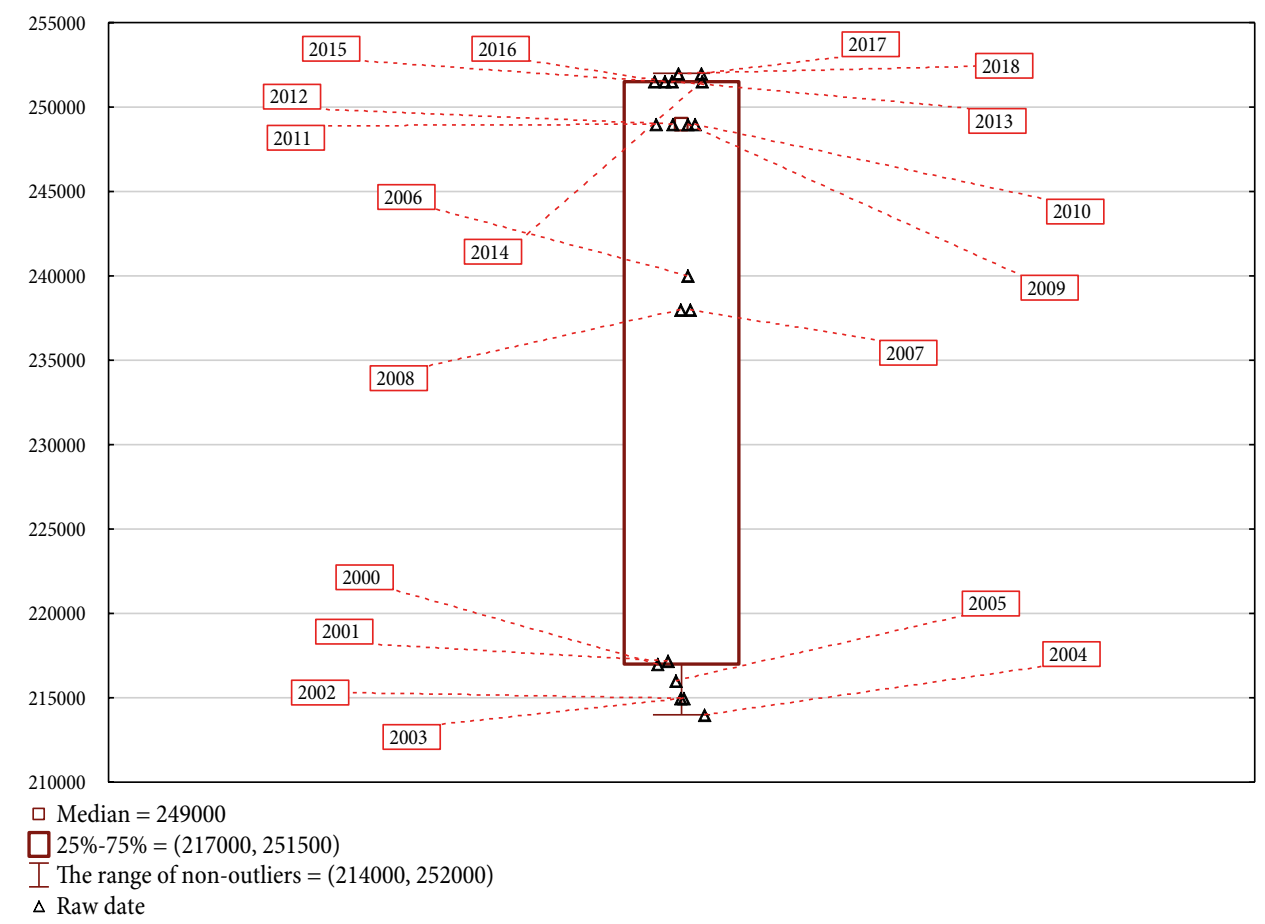

Figure 3. Figure box plot graph of the primary data on the size of the Saudi Arabian army in 2000-2018 Source: own study based on: The World Bank, March 9, 2020

The data presented in Figure 3 shows that there are no outliers and extreme values. The median fluctuates around the level of 237695. The primary data observed between 2006-2011 are closest to the median. The primary data from 2000-2005 are furthest from the median. 
A zero-one multiple regression model (Table 2) was then constructed to confirm the trend in the primary time series of Saudi Arabian soldier data. Three predictors were used to create it.

Table 2. Multiple regression model

\begin{tabular}{|c|c|c|c|c|c|c|}
\hline \multirow[t]{2}{*}{$\mathrm{N}=13$} & \multicolumn{6}{|c|}{$\begin{array}{c}\mathrm{R}=, 91463068 \mathrm{R}^{\wedge} 2=, 83654929 \text { Correctness } \mathrm{R}^{\wedge} 2=, 80385915 \\
\text { Standard terror of estimation: } 2387,3\end{array}$} \\
\hline & $\mathbf{b}^{*}$ & B1. std. & b & Bł. std. & $\mathbf{t}(\mathbf{1 0})$ & p \\
\hline Absolute term & & & 234363,6 & 2336,721 & 100,2959 & 0,000000 \\
\hline $\mathrm{t}$ & 2,38860 & 0,554603 & 3306,2 & 767,658 & 4,3069 & 0,001545 \\
\hline$t \wedge 2$ & $-1,59395$ & 0,554603 & $-153,3$ & 53,356 & $-2,8740$ & 0,016554 \\
\hline
\end{tabular}

Source: own study based on: The World Bank, March 9, 2020

The constructed multiple regression model was very well fitted. The multiple $\mathrm{R} \wedge 2$ was 0.91 . Significant predictors were variables in the form: $\mathrm{t}, \mathrm{t} \wedge 2$ and $\operatorname{lnt}$. The obtained values of the pvalu index of the $t, \mathrm{t} \wedge 2$ and lnt predictors confirm the existence of the trend. The standard error of the estimation was 2387,3.

The analyses resulted in detecting an upward trend in the primary data on the number of soldiers in Saudi Arabia in 2006-2018. Critical analysis of the literature allows the choice of Holt's exponential smoothing method and Klein's model for primary time series forecasting.

Figure 4 and Table 3 show the Saudi Arabian army's size forecasts after using Holt's exponential smoothing method and Klein's model for 2019-2021.

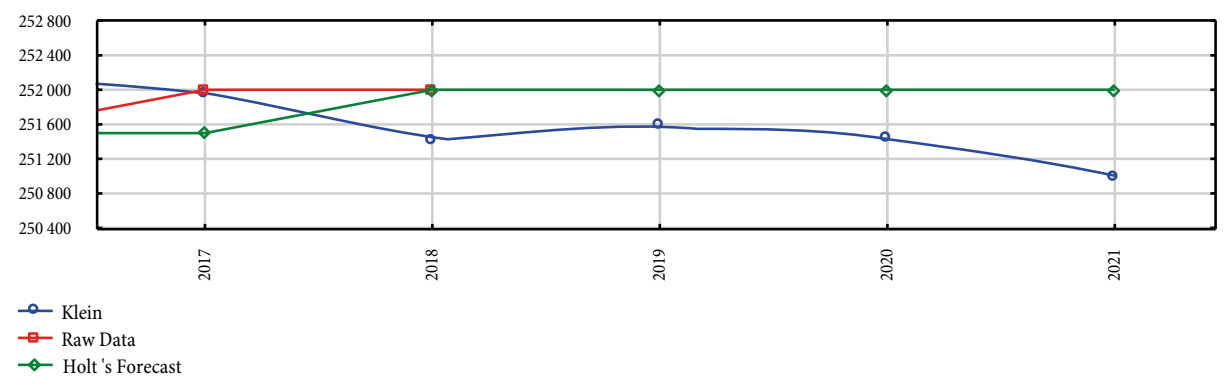

Figure 4. Forecast of the number of soldiers in the Saudi Arabian army for 2019-2021 with the actual values outlined and the residuals of the forecast obtained Source: own study based on: The World Bank, March 9, 2020

The forecast of the number of soldiers for 2018-2021 shows a trend similar to the constant one with a decreasing tendency, visible in the analyzed primary data of the Saudi Arabia time series. 
Table 3. Forecast of the number of soldiers in the Saudi Arabian army for 2019-2021 with the use of Holt's exponential smoothing method and Klein's model

\begin{tabular}{ccc}
\hline Year & Klein & Holts \\
\hline 2019 & 251594 & 252000 \\
\hline 2020 & 251454 & 252000 \\
\hline 2021 & 251006 & 252000 \\
\hline
\end{tabular}

Source: own study based on: The World Bank, March 9, 2020

The forecast made using the Holt-Winters method is constant and remains at 252000 soldiers in 2019-2021, and in the case of Klein's model, it shows a slight downward trend. In 2019, the forecast using Klein's model was 251594, while in 2021, it decreased to 251006 soldiers.

Then, for research purposes, analysis and evaluation of the forecast of residuals made using Holt's exponential smoothing method and Klein's model for 2019-2021 were carried out (Table 4).

Table 4. Error analysis of the forecast obtained after the application of Holt's exponential smoothing method and Klein's model

\begin{tabular}{lcc}
\hline Error type & Klein & Holts \\
\hline $\begin{array}{l}\text { Mean absolute percentage } \\
\text { error }\end{array}$ & $0,613 \%$ & $0,959 \%$ \\
\hline
\end{tabular}

Source: own study based on: The World Bank, March 9, 2020

The analysis presented in Table 4 shows that Klein's model in which MAPE was 0,613\% is the best forecasting method.

\section{Summary and Conclusions}

A comparative analysis of the number of soldiers in the armies of Saudi Arabia and Russia showed no dependency. The number of soldiers in the Russian army is 5.77 times the number of Saudi Arabia. It should also be emphasized that the index of dynamics with a constant basis for the considered time series of the number of soldiers in the Saudi Arabian army showed a strong upward trend. On the other hand, the time series indices for the number of soldiers in the Russian army were alternately positive and negative every few elements, which indicates that there is no dynamic trend.

The forecast made using the Holt-Winters method is constant and remains at 252000 soldiers in 2019-2021, and in the case of Klein's model, it shows a slight downward trend. In 2019, the forecast using Klein's model was 251594, while in 2021, it decreased to 251006 soldiers. The built Klein's model turned out to be the best forecasting method. 
The research hypothesis put forward at the beginning of the study has been verified. The mean absolute percentage error (MAPE) was $0,613 \%$. Therefore, it can be assumed that the obtained forecast is very good.

The use of Klein's model, with the observed dependencies in the considered time series of the number of soldiers in the Saudi Arabian army, may improve the forming of a personnel strategy in the analyzed subject of research, and it is important in terms of ensuring the military security of the country under consideration.

\section{References: $w$}

Armstrong, M. (2007). Zarządzanie zasobami ludzkimi. Walters Lower Business.

Cieślak, M. (2004). Prognozowanie gospodarcze. PWN.

Cieślak, M. (Ed.). (2001). Prognozowanie gospodarcze. Metody i zastosowanie. PWN.

Czerwiński, Z., Guzik, B. (1980). Prognozowanie ekonometryczne. PWE.

Defence24. (2019, September 20). Analitycy o ataku na Arabię Saudyjska: budżet wojskowy to nie wszystko. https://www.defence24.pl/analitycy-o-ataku-na-arabie-saudyjska-budzet-wojskowy-to-nie-wszystko Dittmann, P. et al. (2016). Prognozowanie w zarzadzaniu przedsiębiorstwem. Wydawnictwo Nieoczywiste - imprint GAB Media.

Gajda, J.B. (2001). Prognozowania i symulacja a decyzje gospodarcze. C.H. Beck.

Kitler,W. (2011). Bezpieczeństwo narodowe RP. Podstawowe kategorie. Uwarunkowania. System. Akademia Obrony Narodowej.

Kozicki, B., Bryczek-Wróbel, P., and Górnikiewicz, M. (2020). The Impact of the Coronavirus Pandemic on Russia’s Economic Security: Analysis of Exchange Rates of Selected Currencies and Energy Resources. European, Research Studies Journal, 228-238. 202010.35808/ersj/1879

Kozicki, B. et al. (2018). Cost forecast in a shipping company. Transport Means 1.

Kucharczyk, M., TVN24. (2021, May 25). Dlaczego Arabowie przegrywaja wojny. https://tvn24.pl/magazyntvn24/dlaczego-arabowie-przegrywaja-wojny,24,547

Legucka, A. (2017, November 11). Wspótpraca Rosji z Arabią Saudyjską:potencjał i ograniczenia. Biuletyn. https://www.pism.pl/publikacje/Wsp_praca_Rosji_z_Arabi_Saudyjsk__potencja_i_ograniczenia

Makridakis, S.G., Wheelwright, S.C., and Hyndman, R.J. (1998). Forecasting methods and applications. John Wiley and Sons.

Matuka, A. (September 2020). COVID-19 Outbreak and US Economic Policy Uncertainty: An ARDL Approach. SSRN Electronic Journal.

Nowak, E. (Ed.). (1998). Prognozowanie gospodarcze. A.W. Placed.

Satomi, E. et al. (April 2020). Alocação justa de recuros de saúde escassos diante da pandemia de COVID-19 Considerações éticas. Einstein, 18(2), 1-5. https://journal.einstein.br/article/fair-allocation-of-scarcemedical-resources-during-covid-19-pandemic-ethical-considerations/

Szcześniak, A. (2020, April 17). Rosja i Arabia Saudyjska - wojna, ropa i pieniądze. http://szczesniak.pl/ rosja-arabia-saudyjska

The World Bank. (2020, March 9). Armed forces personnel, total - Saudi Arabia, Russian Federation. https:// data.worldbank.org/indicator/MS.MIL.TOTL.P1?locations=RU-SA 
Urban, D. (2016, April 01). Assessing Saudi Arabia's Military Might. https://www.forces.net/services/triservice/assessing-saudi-arabias-military-might

Zhu, N., Zhang, D., Wang, W. et al. (2020, January 24). A Novel Coronavirus from Patients with Pneumonia in China, 2019. New England Journal of Medicine. 383(8), 727-733. https://www.nejm.org/doi/10.1056/ NEJMoa2001017 